УдК 621.039:005.35

\title{
СОЦИАЛЬНАЯ БЕЗОПАСНОСТЬ АТОМНЫХ ПРЕДПРИЯТИЙ: СОЦИАЛЬНО-ИСТОРИЧЕСКИЙ АНАЛИЗ
}

\author{
Кареева Анна Петровна, \\ karenina3010@rambler.ru \\ Северный (Арктический) Федеральный университет им. М.В. Ломоносова, \\ Россия, 163002, г. Архангельск, набережная Северной Двины, 17
}

Кареева Анна Петровна, соискатель, Северный (Арктический) Федеральный университет им. М.В. Ломоносова.

В статье рассматривается социальная безопасность с позиции социального института. Опираясь на теорию институциональных матриц С.Г. Кирдиной, выделены внутренняя (устойчивая) структура данного института и поверхностная (институциональная). К внутренней структуре относятся такие элементы, как глобальность, систематичность проявления, проникновение во все уровни социума, сформированность устойчивых социальных отношений, наличие чувства страха, превентивный характер используемых мер по устранению негативных последствий социальных рисков. Поверхностную структуру составляют виды безопасности. В приложении к российскому предприятию проведен анализ социальной безопасности на макро-, мезо- и микроуровнях. На макроуровне субъектом социальной безопасности выступает отрасль. Отраслевое руководство стремится обезопасить входящие в состав отрасли предприятия от негативных последствий социальных рисков. Для этого формирует принципы, стратегию, тактику, социальную политику и направления, единые для всех отраслевых предприятий. Выделены восемь направлений социальной политики, которые современное предприятие может использовать для минимизации негативных последствий, возникающих в его социальной среде рисков. Дивизион (мезоуровень) и конкретное предприятие (микроуровень) выступают объектами социальной безопасности. Принцип минимального универсума, предложенный В.Г. Немировским, позволил выявить три уровня социальной безопасности предприятия (вещественно-энергетический, функционально-организационный, информационный). Социально-исторический анализ помог проследить социальную безопасность конкретных промышленных предприятий атомной отрасли, таких как ГХК, СХК и ПО «Маяк», в разные исторические периоды их существования (период становления, расцвета, кризиса и модернизации). Проведенный анализ позволил утверждать, что каждый исторический период развития предприятия оказывает прямое влияние на социальную безопасность атомных предприятий. Также удалось выявить уровни социальной безопасности для каждого из них.

Ключевые слова: Социальный риск, социальная безопасность, социальный институт, рискогенное общество, теория институциональных матриц, принцип минимального универсума, метод качественного анализа документов.

Современное российское общество рискогенно. Риски постоянно культивируются, даже бездействие влечет за собой их появление [1-4].

Люди ежедневно сталкиваются с институциональными средами риска. Находясь в ситуации неопределенности, они вынуждены принимать решения, ориентироваться на мнение разных экспертов для того, чтобы нивелировать негативные последствия того или иного социального риска. «Обезопасить себя» становится для них первоочередной потребностью.

Несмотря на то, что процесс изучения социальной безопасности начался с конца XIX в., ученые до сих пор по-разному трактуют ее. Так, общетеоретические аспекты социальной безопасности изучают Р.Г. Яновский [5], В.Н. Кузнецов [6], Д.В. Зеркалов [7], 
В.Н. Келасьев [8], Г.Г. Пирогов [9], В.К. Левашов [10], А.Г. Антипьев [11] и др. В.Н. Кузнецов видит ее частью национальной безопасности, В.К. Левашов рассматривает через глобализацию и теорию устойчивого развития. Р.Г. Яновский использует понятие «социальная безопасность» для обозначения безопасности от целого комплекса разных угроз населению, причем не только социального, но и экономического, экологического и другого характера. Отдельные социальные риски и виды социальной безопасности рассматривают Н.Н. Малютина [12], Л.М. Лескина, Н.П. Головкова [13] (медицинские аспекты социальной безопасности), П.А. Кисляков [14], Д.В. Савочкин [15] (социальная безопасность образования), М.Б. Лига [16] (социальная безопасность семьи и молодежи). В привязке к предприятию социальную безопасность изучают Р.И. Литвин [17], С.Ю. Иванов [18], Е.В. Лазева [19], В.Ф. Щелоков [20] и др.

В исследовании безопасность и социальная безопасность рассматриваются с позиции институционального подхода. В современном российском рискогенном обществе безопасность выступает социальным институтом, который направлен на поддержание стабильности на различных уровнях социума. Он вносит определенный порядок в ситуацию неопределенности, не позволяет приемлемым для общества рискам трансформироваться в угрозу для существования отдельного человека, социальных групп или всего общества. Данный институт глобален, формирует социальные отношения, которые можно охарактеризовать как «стремление достичь относительной безопасности в ситуации социального риска» и современную идеологию, которая разделяется большинством. Он также помогает человеку избавиться от социального страха. Опираясь на теорию институциональных матриц С.Г. Кирдиной [21], в институте безопасности выделяется внутренняя (устойчивая) и поверхностная (институциональная) структуры. К внутренней структуре относятся такие элементы, как «глобальность, систематичность проявления, проникновение во все уровни социума, сформированность устойчивых социальных отношений, наличие чувства страха, превентивный характер используемых мер по устранению негативных последствий социальных рисков» [22]. Поверхностную структуру составляют виды безопасности. Их наличие обусловлено современными российскими культурно-историческими условиями и институциональными средами риска, характерными для российского общества. Социальная безопасность как раз и является одним из элементов поверхностной структуры института безопасности, т. е. выступает социальным институтом.

В исследовании рассматривается социальная безопасность российского предприятия и анализируется с помощью качественного анализа документов, социальной безопасности отдельных промышленных предприятий атомной отрасли в исторической ретроспективе.

Воспринимая социальную безопасность с позиции социального института, отметим, что она пронизывает все уровни предприятия, от макро- до микроуровня. На макроуровне субъектом социальной безопасности выступает отрасль. Дивизион (мезоуровень) и конкретное предприятие (микроуровень) выступают объектами социальной безопасности. Отраслевое руководство понимает, что входящие в ее состав предприятия находятся в рискогенном обществе, поэтому постоянно стремится обезопасить их от негативных последствий социальных рисков. Для этого формирует принципы, стратегию, тактику, социальную политику и ее направления единые для всех отраслевых предприятий. При этом социальная политика выступает средством, используя которое руководство отрасли стремится минимизировать негативные последствия социальных рисков. Направления, заложенные в ней, выступают мерами, призванными не допустить трансформацию приемлемого риска в социальную угрозу для работника, группы работников или целого предприятия. Всего выделено восемь направлений социальной 
политики, которые современное российское предприятие может использовать для минимизации негативных последствий социальных рисков, а также сами социальные риски. К направлениям социальной политики относим экономическое благосостояние работника, его производственную безопасность, профессиональный рост, творческую активность, производственные и социально-бытовые условия труда, ощущение работником социальной стабильности и получение им обратной связи. Данные направления призваны минимизировать негативные последствия таких социальных рисков, как снижение экономического благосостояния работника, его производственной и экологической безопасности, здоровья, социально-бытовых условий труда, научно-технического и технологического потенциала, социальной стабильности предприятия в глазах работника и значимости для него обратной связи. Итогом социальной безопасности выступает ее результативность. Положительная или отрицательная результативность оказывает прямое влияние на производственный социум, который формируется на предприятии.

Микроуровень любого предприятия составляют наемные работники, которые продают свой труд, вступая в трудовые отношения. Именно они предъявляют отраслевому руководству главное требование обезопасить свою производственную жизнь от социальных рисков. При этом они испытывают страх. Страх потерять самое главное, что у них есть - вознаграждения за трудовые отношения. В основе вознаграждений лежат различные условия труда, сложившиеся на производстве. Именно они подвержены изменению при возникновении рискогенных ситуаций. Стремление достичь относительной безопасности формирует между работниками и руководством устойчивые социальные взаимоотношения, которые проявляются через коммуникацию и активное доверие, и призваны сохранить возникающие на предприятии риски в категории «приемлемые». Только в том случае, когда руководству отрасли/дивизиона/предприятия удается сохранить социальные риски, возникающие в социальной среде конкретного предприятия в категории «приемлемые», у работников снижается страх потери вознаграждения. В этом случае социальная безопасность признается результативной. При положительной результативности в социальной среде предприятия формируется производственный социум, повышающий у работников уверенность в сохранении вознаграждения за трудовые отношения. И наоборот, отрицательная результативность снижает такую уверенность.

Принцип минимального универсума, предложенный В.Г. Немировским [23], позволил выявить уровни социальной безопасности предприятия. В основе данных уровней лежат потребности работников, которые они удовлетворяют с помощью существующих на предприятии условий труда. Отметим, что работники считают предприятие социально безопасным для себя только в том случае, если социальная безопасность, сложившаяся на нем, сохраняет существующие условия труда и позволяет работникам через них удовлетворять свои потребности. Так при удовлетворении повседневных потребностей (в еде, жилье, одежде и т. д.) социальная безопасность предприятия находится на вещественно-энергетическом уровне. При удовлетворении потребностей в общении она находится на функционально-организационном уровне, при удовлетворении потребностей в управлении производством, в профессиональном росте, в творческой инициативе на информационном уровне. Переход между уровнями возможен только в том случае, когда все потребности более низкого уровня удовлетворены.

\section{Методология}

При помощи метода сочииально-исторического анализа документов проанализированы уровни социальной безопасности отдельных промышленных предприятий атомной отрасли, таких как Горно-химический комбинат (г. Железногорск, Краснояр- 
ский край), Сибирский химический комбинат (г. Северск, Томская область) и Производственное объединение «Маяк» (г. Озерск, Челябинская область). Данный анализ также позволил изучить социальную безопасность предприятий в исторической ретроспективе (период становления, расцвета, кризисный период и период модернизации).

Метод качественного анализа документов распространен при проведении социологических исследований. Так качественный анализ в своих исследованиях использовали Л.Н. Депутатова, К.А. Шишкина [24], М.Г. Меерович [25], И.А. Григорьева [26], И.П. Попова, А.Л. Темницкий [27], А.В. Дмитриев, Г.А. Пядухов [28], П.М. Козырева [29] и др.

Объектом исследования в статье выступает социальная безопасность, сложившаяся на отдельных промышленных предприятиях атомной отрасли, а предметом исследования - направления социальной политики, рассмотренные в исторической ретроспективе. Целью исследования стал анализ данных направлений социальной политики. Гипотеза исследования - степень реализации того или иного направления социальной политики напрямую зависит от того, какие социальные риски возникали на нем в определенный исторический период его существования. Для проведения социально-исторического анализа были использованы открытые служебные и личные документы, в которых отражены данные по реализации направлений социальной политики изучаемых атомных предприятий с 1948 по 2020 г. (СХК, ГХК, ПО «Маяк»). Всего было проанализировано 240 служебных и личных документов. За единицу анализа взяты восемь направлений социальной политики современного российского предприятия, такие как экономическое благосостояние работника, его производственная безопасность, профессиональный рост, творческая инициатива, производственные и социально-бытовые условия труда, ощущение работником социальной стабильности и получение обратной связи.

\section{Результаты}

Рассматриваемые в исследовании предприятия с момента своего возникновения являлись частью российской атомной отрасли, создавались как военные производства, расположенные на закрытых административно-территориальных образованиях (ЗАТО). Тема безопасности всегда была актуальна для них. Ведь сам производственный процесс предполагал наличие и соблюдение персоналом множества регламентов безопасности. Работники, в свою очередь, предъявляли руководству своих предприятий главное требование - сделать их производственную жизнь защищенной от социальных рисков.

\section{Вещественно-энергетический уровень социальной безопасности}

Данный уровень включает в себя следующие направления социальной политики: экономическое благосостояние работника, производственная безопасность, производственные и социально-бытовые условия труда.

Экономическое благосостояние работника. Социально-исторический анализ показал, что в период становления и расцвета все изучаемые предприятия атомной отрасли не испытывали сложности с выплатой своим работникам денежного вознаграждения (зарплаты). Она была самой высокой в народном хозяйстве СССР, выплачивалась вовремя, согласно тарифным окладам и районным коэффициентам, доплатам за вредные условия труда, а на ГХК еще и за подземное расположение комбината. Оклады работников в зависимости от рабочего места были разделены на три тарифные сетки (А, B, C). От того, по какой сетке трудился работник, зависел уровень его денежного вознаграждения. Помимо тарифных окладов на атомных предприятиях была предусмотрена система премирования работников за рационализаторские предложения, за совершенствование технологии производства. Впервые существенные сложности в системе 
оплаты труда наметились в 1990-е гг., в кризисный период существования предприятий, в который отмечается резкое снижение суммы материального вознаграждения работников атомной отрасли в сравнении с заработными платами в других отраслях промышленности. Рост зарплаты начинает отставать от стоимости потребительской корзины, ее выплата становится нерегулярной. Из-за сокращения финансирования со стороны отрасли предприятия теряют возможность индексировать заработную плату вслед за ростом инфляции. Для минимизации негативных последствий риска снижения экономического благосостояния своих работников руководство СХК и ПО «Маяк» начинает выплачивать надбавки сотрудникам за высокие достижения. Однако они носят персонифицированный характер, а их выдача приурочивается к юбилейным датам. На ГХК первое существенное повышение окладов произошло только в 2006 г. Существенный пересмотр системы оплаты труда наметился на изучаемых атомных предприятиях в период модернизации (начало $2000-\mathrm{x}$ гг.). По инициативе Госкорпорации «Росатом» была разработана и внедрена Единая унифицируемая система оплаты труда (ЕУСОТ). Она позволила проводить мониторинг уровня заработной платы работников, корректировать ее отставание от среднерыночных показателей. Благодаря внедрению переменной части оплаты труда (ИСН) сумма материального вознаграждения, которую получает работник, оказалась в прямой зависимости от его личных достижений и вклада в развитие предприятий. На сегодняшний день уровень зарплат у работников ПО «Маяк» в среднем в два раза выше, чем у остальных жителей Озерска и Челябинской области. Зарплата на СХК на 91,5\% выше, чем средняя зарплата по Томской области. Наименьшая разница по средней зарплате в регионе наблюдается у работников ГХК. Работники комбината получают только на 50 \% больше, чем остальные работники Красноярского края.

Социальный пакет атомщиков на протяжении всех периодов развития данных предприятий отличался своей значительностью. В связи со спецификой комбинатов на них действовали различные социальные льготы и компенсации за сложные условия труда. Они устанавливались в соответствии с федеральными законами и закреплялись в коллективном договоре предприятий. Льготы и компенсации распространялись на всех работников комбинатов, но их полнота и разнообразие зависели от тарифных сеток. Так работники основного производства (тарифная сетка А) получали трехразовое лечебно-профилактическое питание, увеличенный до 2,5 месяцев ежегодный оплачиваемый отпуск, льготное пенсионное обеспечение (выход на пенсию в 50 лет и увеличенные пенсионные выплаты) и т. д. Работники других тарифных сеток (В и С) не имели таких льгот. При этом всем работникам предприятий были доступны единовременные выплаты при уходе на пенсию или при увольнении на пенсию по инвалидности, материальная помощь на погребение, зубопротезирование, оплату сложных офтальмологических операций и т. д. Сложности с сокращением социального пакета возникли в кризисный период. Так, на ГХК и СХК из-за отсутствия финансирования в 1990-е гг. были исключены из коллективного договора отдельные льготы и компенсации. Их возврат был осуществлен только в период модернизации.

Производственная безопасность работника. В основе данного направления социальной политики лежит научная организация труда (НОТ), которая охватывает весь технологический процесс от организации рабочего места сотрудника до работы производственных коллективов и всего предприятия. Основная цель НОТ сделать технологический процесс максимально безопасным для работников. Особенность изучаемых атомных предприятий наложила отпечаток на их производственную деятельность. Изза того, что основной продукт, получаемый комбинатами, был связан с радиоактивностью, помимо традиционных элементов, таких как внутренний трудовой распорядок, 
хронометраж, разделение труда, паспортизация рабочих мест и т. д., в производственной среде формируются и специфические элементы организации труда. К ним относятся биологическая защита, автоматизация рабочих процессов, дистанционность, использование дозиметрических приборов, дублирующих аппаратов, четкое следование нормативной документации, производственным инструкциям и т. д. Специфическая система организации труда в период становления комбинатов формировалась с нуля. Наибольшие сложности при этом возникли на ПО «Маяк», который стал первым атомным предприятием. До его строительства все специфические элементы НОТ существовали только в лабораторных масштабах. Промышленная эксплуатация ПО «Маяк» внесла в них свои коррективы. Работникам СХК и ГХК оказалось значительно проще в формировании своей промышленной безопасности. При содействии отраслевого министерства опыт маяковцев был распространен и на них. Однако ГХК оказался в более сложных условиях, чем СХК. Ведь его основные заводы расположились в горной выработке. Это затруднило внедрение специфических элементов НОТ. Социально-исторический анализ показал, что окончательно традиционная и специфическая системы организации труда сформировались на данных атомных предприятиях уже в период расцвета. В кризисный период они сохранили свою работоспособность. Переосмысление системы научной организации труда начинается на них в период модернизации (с 2000-х гг.). Такая необходимость возникла в связи с выходом атомных предприятий на международный рынок. С подачи Госкорпорации «Росатом» в технологической среде предприятий начинает централизованно внедряться новая производственная система - ПСР. Она вобрала в себя лучшие достижения и разработки российской атомной отрасли и новейшие достижения международных компаний, адаптированные под атомную специфику.

Производственные условия труда работника составляют основу производственной инфраструктуры атомных предприятий и направлены на решение ряда задач, таких как сохранение здоровья работника и предупреждение возникновения у него профессиональных заболеваний. Социально-исторический анализ документов показал, что производственные условия труда совершенствовались на протяжении всех исторических периодов развития изучаемых комбинатов. Наибольшие сложности с их реализацией возникли в период становления. Здесь вновь первопроходцем стал ПО «Маяк». Совместно с научными центрами страны работники данного предприятия сформулировали общие принципы, нормы и правила по охране здоровья персонала, разработали алгоритмы проведения медосмотров, их периодичность, а также критерии отбора сотрудников для атомной отрасли в части здоровья. Полученный опыт с подачи отраслевого министерства был перенесен на ГХК и СХК. К концу периода становления на всех изучаемых нами атомных комбинатах сформированы все необходимые меры и регламенты по контролю в области охраны труда, пожарной, ядерной, радиационной и экологической безопасности, санитарно-гигиенических условий труда, организована централизованная доставка сотрудников на производство. Наиболее значимые позиции, затрагивающие производственную инфраструктуру, закреплены в коллективном договоре. Для профилактики профессиональных заболеваний создана система заводского здравоохранения, санаторно-курортного лечения и лечебно-профилактического питания. Первые риски в ее функционировании возникли в кризисный период развития предприятий в связи с сокращением финансирования. Уменьшилось количество путевок в санатории страны, выделяемые атомщикам. При этом регулярные медосмотры и лечение в санаториях в городской черте сохранились. ГХК даже удалось в этот период запустить новое здание санатория-профилактория «Юбилейный» и оснастить его современным медицинским оборудованием. Сложности с функционированием системы здравоохранения сохранились на 
всех комбинатах и в период модернизации. В первую очередь они связаны с нехваткой профессиональных цеховых врачей общего и узкого профиля и преобладанием формального подхода к проведению обязательных медицинских осмотров. Наиболее остро проблему нехватки врачебного персонала ощущают сотрудники СХК и ГХК.

Социально-бытовые условия труда работника, или социально-бытовая инфраструктура, в начале периода становления ГХК, СХК и ПО «Маяк» только формируется. Ведь строительство комбинатов происходило удаленно от крупных промышленных центров страны в малонаселенной местности или в тайге. Их создание началось со строительства самой необходимой инфраструктуры, такой как прокладка дорог, доставка строительного материала, строительство первых жилых бараков и т. д. Поэтому начальный период в истории всех изучаемых нами атомных предприятий можно описать как самый сложный в социально-бытовом плане: бездорожье, грязь, деревянные бараки с минимальным количеством мебели (печка, кровать, стол) и плохим отоплением. При этом на промышленной площадке и в городской черте идут масштабные строительные работы. Формируется система спецснабжения городов, в которых располагаются строящиеся атомные комбинаты. Руководство предприятий, несмотря на образование городских советов, является их истинным руководителем. Сами предприятия воспринимаются как градообразующие. При поддержке отраслевого министерства поощряется спортивная и культурная жизнь работников, ведется активное жилищное строительство, а построенные квартиры распределяются среди нуждающегося персонала. Социально-исторический анализ документов показал, что в период становления и расцвета СХК, ГХК и ПО «Маяк» выступали главными застройщиками своих городов (Северска, Железногорска, Озерска). Благодаря тому, что руководство комбинатов исправно финансировало данный вид деятельности, ежегодный прирост жилого фонда в городах присутствия атомных комбинатов составлял в среднем 10-15 тысяч квадратных метров. Часть строящегося жилья передавалась в муниципалитет. Одновременно с жильем строились и объекты соцкультбыта (поликлиники, кинотеатры, школы, детские сады, административные здания, спортивные объекты и т. д.). На балансах предприятий оказались многие из построенных спортивных и культурных объектов: на ГХК спорткомплекс «Октябрь», лагерь «Звездочка», на СХК - лагерь «Восход», на ПО «Маяк» - спорткомплекс «Химик» и т. д. Роль комбинатов, как основных застройщиков городов, начинает снижаться в кризисный период. Из-за отсутствия финансирования резко сокращаются темпы строительства. Так, ГХК за 1995-1997 гг. смог построить в Железногорске только два дома. Похожая картина наблюдается в Северске и Озерске. Чтобы уменьшить социальные риски, связанные с нехваткой жилья, в практику начинают внедряться новые меры. Среди них сдача квартир под самоотделку, привлечение средств работников на достройку домов, приобретение жилья за выкуп. Однако данные меры не смогли полностью устранить возникающие социальные риски. Поэтому в период модернизации комбинаты полностью утратили свою роль застройщиков атомных городов. Сегодня жилищный вопрос на них решается, но говорить о массовом выделении жилья больше не приходится. На ГХК и СХК руководство помогает решать жилищные проблемы только представителям критических специальностей и работникам, привлекаемым из других городов. На ПО «Маяк» жилищная политика носит более массовый характер. В отличие от ГХК и СХК руководство данного комбината помогает решить жилищный вопрос тем сотрудникам, которые признаются нуждающимися в улучшении жилищных условий, т. е. имеют площадь менее 12 метров на человека. Объекты соцкультбыта, начиная с кризисного периода, комбинаты также передают в муниципалитеты. Руководство комбинатов все больше отстраняется от вме- 
шательства в городскую жизнь. Роль предприятий как градообразующих нивелируется. В городской жизни все больше обостряются различные социально-бытовые проблемы. Для всех изучаемых атомных городов характерны узость рынка труда, сложности с медицинским обслуживанием, снижение рынка продуктов питания и бытовых товаров по сравнению с рядом расположенными крупными городами. Для Северска характерно обострение экологических проблем, возникших по вине городских служб. В Железногорске после закрытия последнего атомного реактора резко выросли тарифы на тепло. Сегодня коммунальные услуги в городе стоят вдвое больше, чем в Красноярске.

Негативные тенденции, характерные для социально-бытовой инфраструктуры Северска, Железногорска и Озерска, отрицательно сказались на работниках предприятий и их жителях. Менталитет «исключительности», «элитарности», который сформировался у них в период становления и развития из-за поддержания отраслевым атомным министерством более благоприятных социально-бытовых условий в черте закрытых городов, был подорван в кризисный период. Начиная с него, работники комбинатов и жители города перестали чувствовать себя особенными, их жизнь постепенно сравнялась с другими окружающими их территориями. Это вызвало у них протест, негативное отношение ко всему происходящему. В период модернизации отдельные отрицательные тенденции у части населения еще больше усугубили негативное отношение ко всему происходящему, у другой - вызвали апатию. Особенно остро негатив и апатия на сегодняшний день проявляются в Железногорске.

\section{Функционально-организационный уровень социальной безопасности}

Уровень включает одно направление социальной политики, а именно ощущение работниками социальной стабильности.

Анализ документальных источников показал, что на начальном этапе периода становления ощущение работниками изучаемых атомных предприятий социальной стабильности двоякое. С одной стороны, на комбинатах ведутся масштабные строительные работы, атомное министерство ставит перед коллективами конкретные цели и задачи. С другой стороны, отсутствие аналогов подобных предприятий вызывает у работников опасение в их успешности. Ведь до запуска ПО «Маяк» в СССР не было ни одного промышленного уран-графитового реактора, а компоненты ядерного оружия получали только в лабораторных масштабах. ГХК вообще по задумке проектировщиков располагался в скальной выработке. Опыта создания такого производства ни в нашей стране, ни в мире не было. Только успешный запуск всех технологических цепочек к концу периода становления укрепил у персонала ГХК, СХК и ПО «Маяк» ощущение социальной стабильности и позволил сохранить данное ощущение на высоком уровне в течение всего периода расцвета, для которого характерен стабильный гособоронзаказ на всех комбинатах, отраслевое и федеральное признание данных предприятий, строительство на каждом из них новых мирных производств и совершенствование существующей оборонной технологии, рост коллективов, формирование династий и т. д. Отметим, что о снижении социальной стабильности впервые упоминается в документальных источниках кризисного периода. К причинам, негативно влияющим на стабильность, мы отнесли снятие гособоронзаказа на получение оружейного плутония, проведение конверсионной политики в отношении предприятий военно-промышленного комплекса, значительное сокращение финансирования из федерального бюджета, критика атомной отрасли со стороны негативно настроенной общественности. На комбинатах закрываются промышленные уран-графитовые реакторы (ГХК - 3, СХК - 5, ПО «Маяк»-7), замораживается строительство новых производств (ГХК - завод РТ-2, ПО «Маяк» - Южноуральская АЭС), 
наблюдается убыль персонала, нехватка финансирования, падает престиж профессии «атомщик». Руководство с помощью внедрения конверсионных направлений старается снизить негативные последствия, вызванные возникающими на комбинатах социальными рисками. В части внедрения конверсии СХК и ПО «Маяк» оказались более успешными, чем ГХК. Созданные ими производства заложили основу дальнейшей деятельности комбинатов и вывели их на международный уровень. В период модернизации данные направления продолжают успешно работать. К ним относятся такие проекты, как «ВОУ-НОУ» (СХК, ПО «Маяк»), переработка и остекловывание зарубежного ОЯТ (ПО «Маяк»), поставка зарубежным партнерам металлического урана, литиевых солей, стабильных изотопов (СХК). ГХК также внедряет конверсионные производства, но выйти на мировой рынок у него не получается. К периоду модернизации изучаемые нами атомные предприятия подходят с разными стартовыми возможностями, т. е. перспективы есть у всех, но они отличаются. На ГХК и СХК у персонала преобладает двойственная позиция относительно своего будущего. С одной стороны, создаются новые производства (ГХК - МОКС-топливо, ОДЦ, СХК - проект «Прорыв», стабильные изотопы, электролиты и т. д.). С другой - часть вспомогательных производств выводится за контур предприятий. Из них создаются «зависимые хозяйственные общества» (3ХO). Так, по завершении данного процесса штат СХК уменьшился в 4,2 раза, штат ГХК сократился на 1,5 тысячи человек. У оставшихся работников обостряется страх «быть сокращенными», что приводит к существенному снижению их уверенности в завтрашнем дне. На ПО «Маяк» наблюдается другая картина. Предприятие снова выполняет работы по реализации гособоронзаказа, а также коммерческие заказы российских и зарубежных партнеров, его численность сохраняется высокой (12,5 тысяч человек). В контуре остаются не только вспомогательные объекты, но и объекты здравоохранения (например, санаторий-профилакторий). При этом на ГХК и СХК они были первыми выведены в ЗХО. Данные положительные тенденции укрепляют в маяковцев ощущение социальной стабильности.

\section{Информационный уровень социальной безопасности}

К данному уровню относятся профессиональный рост, творческая активность и получение работником обратной связи.

Профессиональный рост работника. Согласно документам в период становления ПО «Маяк», как первое атомное производство, столкнулось с отсутствием специализированных кадров, таких как атомщики и радиохимики. Их подготовкой параллельно со строительством комбината занялись сами ученые, разработавшие атомную технологию. Так будущих эксплуатационников атомных реакторов ПО «Маяк» готовили в Москве на базе Лаборатории № 2 (сейчас Курчатовский институт). Будущие радиохимики обучались в Радиевом институте Академии наук СССР в Ленинграде. В дальнейшем кадрами для ГХК и СХК занимались уже специализированные вузы и кафедры (Москва, Ленинград, Свердловск, Горький, Томск, Новосибирск и т. д.). Отраслевое министерство практиковало ротацию кадров между атомными комбинатами. Согласно приказам по личному составу перед пуском первого атомного реактора на ГХК с ПО «Маяк» и СХК приехало более 400 человек. К концу периода становления на всех комбинатах начинает формироваться своя система подготовки кадров, которая успешно работает в течение периода расцвета. Создаются курирующие отделы, внедряется система наставничества, отраслевые и корпоративные конкурсы, в городах открываются профессиональные техникумы и филиалы вузов (ГХК - КПК, ПЛ-10, СХК - СТИ, ПО «Маяк»техническое училище, филиал МИФИ). Предприятия и коллективы активно сотрудни- 
чают с профильными вузами и кафедрами страны (ВНИПИЭТ, ВНИИНМ, ВНИИХТ и т. д.), практикуются стажировки работников на технологически похожих предприятиях. Финансовые сложности кризисного периода внесли коррективы в систему подготовки кадров. Так на ГХК сократилось количество привлекаемых молодых работников, институты Северска и Озерска стали готовить специалистов не только атомной направленности. Снижаются стажировки, нивелируется система наставничества, уменьшается число отраслевых и корпоративных профконкурсов. Только в период модернизации к данному направлению социальной политики вновь повышается внимание со стороны отраслевого министерства и руководства комбинатов. В рамках отрасли создаются образовательные учреждения, занимающиеся повышением квалификации атомщиков (Корпоративная академия Росатома, Техническая академия Росатома), повышается сотрудничество с ведущими и профильными вузами регионов (ТПУ, СФУ, МИФИ и т. д.), растет доля дистанционного обучения на отраслевой платформе РЕКОРД-mobile, внутренние программы обучения согласуются с отраслью, возрождается система наставничества (менторинг), растет число конкурсов профессионального мастерства («Человек года Росатома», AtomSkills, WorldSkills). Для выпускников школ организован целевой набор в профильные вузы.

Творческая иниииатива работника. Анализ документальных источников показал, что творческая инициатива во все периоды развития активно развивается и востребована на изучаемых атомных комбинатах. Для этого на них созданы все необходимые производственные условия, а отраслевое министерство поддерживает и поощряет рационализаторскую и изобретательскую деятельность персонала. Ее курирование возложено на научно-технические советы предприятий. Лучшие разработки поощряются материально и морально (выплата денежного вознаграждения и присуждение наград корпоративного, отраслевого и федерального значения). В период становления и расцвета основное внимание работников, проявляющих творческую инициативу, было сосредоточено на совершенствовании технологического процесса, увеличении количества и качества выпускаемой оборонной продукции, разработке инновационных проектов по внедряемым мирным направлениям. В кризисный период акцент смещен на конверсионные производства. При сохранении морального поощрения значительно снижается сумма материальных выплат. В период модернизации творческая инициатива связана в большей степени с внедрением на комбинатах новых направлений деятельности (проект «Прорыв» на СХК, «сухие» хранилища на ГХК, создание системы по обращению с ТРО всех видов на ПО «Маяк» и т. д.).

Получение работником обратной связи. Каждый период развития ГХК, СХК и ПО «Маяк» внес свой вклад в развитие системы обратной связи между работниками и руководством комбинатов и отрасли. В период становления главной формой взаимодействия являются собрания различного формата (профсоюзные, оперативные, производственные, планерки, торжественные, молодежные). В них активное участие принимает руководство и приглашаемое отраслевое министерство. В период расцвета внедряются новые формы взаимодействия, такие как сбор вопросов и пожеланий, личные приемы директора предприятия по производственным и частным вопросам. В кризисный период сохраняются все ранее внедренные формы взаимодействия, но новых не появляется. При этом к концу 1990-х годов только на ГХК наблюдается резкое сокращение количества встреч директора с персоналом, практически полностью прекращается сбор вопросов от коллективов. Модернизация предприятий внесла новые формы во взаимодействие между работниками и руководством комбинатов и отрасли. Появляется онлайн-общение работников предприятия с руководством отрасли (дни информи- 
рования), общение генерального директора с персоналом (дни директора), вертикальное каскадирование информации. Одновременно совершенствуются традиционные формы, такие как производственные планерки, собрание по принятию поправок в коллективный договор, молодежные встречи, торжественные собрания, корпоративные праздники, профсоюзные собрания. Общение между генеральным директором и работниками становится доступно через сайты предприятий. Отметим, что в период модернизации сложности с обратной связью нам удалось найти только на ГХК. Это в первую очередь связано с внутренним каскадированием информации. Внедряемые в рамках комбината в практику встречи работников с топ-менеджерами в формате неформального общения (разговор за чашкой чая) призваны частично решить эту проблему.

\section{Выводы}

Завершая социально-исторический анализ социальной безопасности таких атомных предприятий, как СХК, ГХК и ПО «Маяк», отметим, что исторические периоды развития оказывают прямое влияние на их социальную безопасность.

Так для периода расцвета данных предприятий уровень социальной безопасности удалось определить достаточно четко. Социальная безопасность данного периода определена как стабильная, т. е. уровень социальной безопасности остается неизменным на протяжении большей части периода. Поэтому в период расцвета социальная безопасность ГХК, СХК и ПО «Маяк» отнесена к информационному уровню. Это значит, что все негативные проявления социальных рисков вещественно-энергетического и функционально-организационного уровня руководству атомной отрасли и конкретных предприятий удалось решить. Сложившиеся на комбинатах условия труда полностью удовлетворяют все потребности работников.

Социальная безопасность периода становления, кризисного периода и периода модернизации характеризуется своей изменчивостью, т. е. начало периода и его конец представлены разными уровнями социальной безопасности. Поэтому о социальной безопасности в эти периоды можно говорить, используя категорию вероятности. Сами же периоды характеризуются как переходные. Уровни социальной безопасности для каждого атомного комбината представлены в таблице.

Таблища. Уровни сощиальной безопасности атомных предприятий в различные исторические периоды развития (расцвет, кризис, модернизация)

Table. Levels of social security of nuclear enterprises in different historical periods of development (flourishing, crisis, modernization)

\begin{tabular}{|c|c|c|c|c|c|c|}
\hline \multirow{3}{*}{$\begin{array}{l}\text { Атомные предприятия } \\
\text { Nuclear plants }\end{array}$} & \multicolumn{6}{|c|}{ Исторические периоды/Historical periods } \\
\hline & \multicolumn{2}{|c|}{ становление/becoming } & \multicolumn{2}{|c|}{ кризис/crisis } & \multicolumn{2}{|c|}{ модернизация/modernization } \\
\hline & начало/start & конец/end & начало/start & конец/end & начало/start & конец/end \\
\hline$\Gamma \mathrm{\Gamma X}$ & ВЭУ & ИУ/IL & ИУ/IL & ВЭУ!/MEL! & /MEL & ВЭУ \\
\hline CXK/SCP & & ИУ/IL & ИУ/IL & ВЭУ/MEL & ВЭУ/MEL & ФOУ/FOL \\
\hline $\begin{array}{l}110 \text { 《Maяк»" } \\
\text { Production association } \\
\text { "Mayak» }\end{array}$ & ВЭУ/MEL & ИУ/IL & ИУ/IL & ВЭУ/MEL & ВЭУ & \\
\hline
\end{tabular}

ВЭУ - вещественно-энергетический уровень социальной безопасности/MEL - material and energy level of social security; ФОУ - функционально-организационный уровень социальной безопасности/FOL - functional and organizational level of social security; ИУ - информационный уровень социальной безопасности/IL - informational level of social security; ! - наибольшее падение уровня социальной безопасности/! - largest drop in social security 


\section{СПИСОК ЛИТЕРАТУРЫ}

1. Giddens A., Sutton P.W. Essential concepts in sociology. - Cambridge: Polity Press, 2017. - 224 p.

2. Beck U. Why 'class' is too soft a category to capture the explosiveness of social inequality at the beginning of the twenty-first century // The British Journal of Sociology. - 2013. - V. 64. - Iss. 1. - P. 63-74.

3. Luhmann N. Theory of society. V. 1. - Redwood City, California: Stanford University Press, 2012. - 488 p.

4. Sorensen M.P. Ulrich Beck: exploring and contesting risk // Journal of Risk Research. - 2018. - V. 21. - Iss. 1. - P. 6-16.

5. Яновский Р.Г. Социальная безопасность России в период стабилизации. - М.: РНЦ РАК, 2003. - 80 с.

6. Кузнецов В.Н. Теория компромисса. - М.: Книга и бизнес, 2010. - 588 с.

7. Зеркалов Д.В. Социальная безопасность. - Киев: Основа, 2012. - 530 с.

8. Келасьев В.Н., Первова И.Л. Социальная компетентность: уровни, структура, стратегии формирования. - СПб.: Астерион, 2019. - 122 с.

9. Пирогов Г.Г. Концепция социальной безопасности // Обозреватель. - 2007. - № 9. - С. 38-49.

10. Левашов В.К. Социально-политическая устойчивость: риски и императивы // Мониторинг общественного мнения: экономические и социальные перемены. - 2013. - № 4 (116). - С. $29-42$.

11. Антипьев А.Г. Современные вызовы «архаичному» российскому обществу // Вестник Пермского университета. - 2011. - Вып. 2 (6). - С. 122-130.

12. Некоторые показатели здоровья работающего населения Пермского края и задачи по его укреплению на ближайшие годы / Н.Н. Малютина, Р.Б. Еремеев, Л.А. Тараненко, А.С. Толкач, В.Г. Костарев // Медицина труда и промышленная экология. - 2012. - № 12. - С. 4-8.

13. Лескина Л.М., Головкова Н.П. Оценка риска нарушения здоровья трудовых коллективов // Здоровье и безопасность на рабочем месте: сб. науч. тр./ гл. ред. И.В. Бухтияров, Т.М. Рыбина. Минск: Поликрафт, 2019. - Т. 1. - Вып. 3. - С. 189-193.

14. Кисляков П.А. Системно-личностная модель здоровьеориентированного образования в вузе // Научный результат. Серия «Педагогика и психология образования». - 2015. - № 2. - С. 49-54.

15. Савочкин Д.В., Труфанов Д.О. Опыт исследования социальной безопасности образовательного процесса в сибирском вузе // SIBERIAN SOCIUM. - 2019. - Т. 3. - №1. - C. 61-72.

16. Лига М.Б. Социальная безопасность и качество жизни: концептуальный анализ // Ученые записки Забайкальского государственного университета. Серия «Философия, социология, культурология, социальная работа». - 2013. - № 4 (51). - С. 170-177.

17. Литвин Р.И. Планирование социальной безопасности предприятия // Вестник Луганского национального университета имени Владимира Даля. - 2019. - № 9 (27). - С. 157-160.

18. Иванов С.Ю. Ресурс влияния профсоюзной организации как фактор удовлетворенности трудом // Социальное партнерство»: опыт, проблемы и перспективы развития: Материалы XVI международной научно-практической конференции. - Ярославль: ЯФ ОУП ВО «АТиСО», 2019. - С. 176-180.

19. Лазева Е.В. Социальная работа на предприятии // Научное сообщество студентов ХХІ столетия. Общественные науки: сб. ст. по мат. XVII междунар. студ. науч.-практ. конф. - Новосибирск, 2014. - № 2 (17). - С. $43-48$.

20. Щелоков В.Ф. Концептуальные основы социологического анализа кадровой безопасности промышленного предприятия и понятие «кадровая сила предприятия» // Вестник Поволжской академии государственной службы имени П.А. Столыпина. - 2008. - № 2 (15). - С. 78-83.

21. Кирдина С.Г. Институциональные матрицы и развитие России: введение в Х-Y теорию. - СПб.: Нестор-История, 2014. - 468 с.

22. Кареева А.П. Социальные риски современного промышленного предприятия // Проблемы анализа риска. - 2015. - № 6 (6-15). - С. 22-30.

23. Немировский В.Г. Представления населения Красноярского края о смысле жизни: структура и динамика (1991-2016 гг.) // SIBERIAN SOCIUM. - 2018. - Т. 2. - № 1. - С. 20-40.

24. Депутатова Л.Н., Шишкина К.А. Мотивация персонала в контексте теории поколений // Вестник Пермского национального исследовательского политехнического университета. Социальноэкономические науки. - 2019. - № 2. - С. 178-191.

25. Меерович М.Г. Жилищная политика в СССР как средство социального управления (1917-1941 гг.) // СОЦИС. - 2014. - № 1. - С. 95-101.

26. Григорьева И.А. Сто лет трансформаций социальной политики в России // Журнал исследований социальной политики. - 2017. - № 4. - Т. 15. - С. 497-514.

27. Попова И.П., Темницкий А.Л. Интеллектуально-профессиональный потенциал: к проблеме структурных изменений // СОЦИС. - 2011. - № 1. - С. 56-67.

28. Дмитриев А.В., Пядухов Г.А. Интеграция трудовых мигрантов в мегаполисе: локальные модели, контекст идентичности (методология и методы исследования) // СОЦИС. - 2013. - № 5. - С. 48-55.

29. Козырева П.М. Финансовое поведение в контексте социально-экономической адаптации населения (социологический анализ) // СОЦИС. - 2012. - № 7. - С. 54-66.

Поступила 23.12.2020 г. 
UDC 621.039:005.35

\title{
SOCIAL SECURITY OF NUCLEAR ENTERPRISES: SOCIO-HISTORICAL ANALYSIS
}

\author{
Anna P. Kareeva, \\ karenina3010@rambler.ru \\ Northern (Arctic) Federal University named after M.V. Lomonosov, \\ 17, Severnaya Dvina embankment, Arkhangelsk, 163002, Russia
}

\begin{abstract}
Anna P. Kareeva, applicant, Northern (Arctic) Federal University named after M.V. Lomonosov.
\end{abstract}
The article examines social security from the social position. Based on the theory of institutional matrices S.G. Kirdina highlighted the internal (stable) and superficial (institutional) structure of this institution. The inner structure includes such elements as globality, systematic manifestation, penetration into all levels of society, formation of stable social relations, fear, preventive nature of the use of measures to eliminate the negative consequences of social risks. The surface structure is made up of types of security. An analysis of social security at macro-, meso- and microlevels was carried out in the appendix to the Russian enterprise. At the macrolevel, the industry is the subject of social security. Industry leadership strives to protect its member enterprises from the negative consequences of social risks. To do this, it forms the principles, strategy, tactics, social policy and its directions that are uniform for all enterprises that are part of it. In total, the article highlights eight areas of social policy that a modern enterprise can use to minimize the negative consequences of risks arising in its social environment. A division (mesolevel) and a specific enterprise (microlevel) are objects of social security. The principle of the minimum universe, proposed by V.G. Nemirovsky, made it possible to identify three levels of social security of an enterprise (material-energy, functional-organizational, informational). Socio-historical analysis helped to trace the social security of specific industrial enterprises of the nuclear industry, such as MCC, SKhK and PA Mayak, in different historical periods of their existence (the period of formation, prosperity, crisis and modernization). The analysis made it possible to assert that each historical period of the enterprise's development has a direct impact on the social security of nuclear enterprises. We were also able to identify the levels of social security for each of them.

Key words: Social risk, social security, social institution, risk-generating society, theory of institutional matrices, principle of the minimum universe, method of qualitative analysis of documents.

\section{REFERENCES}

1. Giddens A., Sutton P.W. Essential concepts in sociology. Cambridge, Polity Press, 2017. 224 p.

2. Beck U. Why 'class' is too soft a category to capture the explosiveness of social inequality at the beginning of the twenty-first century. The British Journal of Sociology, 2013, vol. 64, Iss. 1, pp. 63-74.

3. Luhmann N. Theory of society. Vol. 1. Redwood City, California, Stanford University Press, 2012. 488 p.

4. Sorensen M.P. Ulrich Beck: exploring and contesting risk. Journal of Risk Research, 2018, vol. 21, Iss. 1, pp. 6-16.

5. Yanovskiy R.G. Sotsialnaya bezopasnost Rossii v period stabilizatsii [Social security of Russia during the period of stabilization]. Moscow, RNTS RAK Publ., 2003. 80 p.

6. Kuznetsov V.N. Teoriya kompromissa [Compromise theory]. Moscow, Kniga i biznes Publ., 2010. 588 p.

7. Zerkalov D.V. Sotsialnaya bezopasnost [Social security]. Kiev, Osnova Publ., 2012. 530 p.

8. Kelasev V.N., Pervova I.L. Sotsialnaya kompetentnost: urovni, struktura, strategii formirovaniya [Social competence: levels, structure, formation strategies]. St. Petersburg, Asterion Publ., 2019. 122 p.

9. Pirogov G.G. Kontseptsiya sotsialnoy bezopasnosti [Social security concept]. Obozrevatel, 2007, no. 9, pp. 38-49.

10. Levashov V.K. Sotsialno-politicheskaya ustoychivost: riski i imperativy [Socio-political resilience: risks and imperatives]. Monitoring obshchestvennogo mneniya: ekonomicheskie i sotsialnye peremeny, 2013, no. 4 (116), pp. 29-42.

11. Antipev A.G. Sovremennye vyzovy «arkhaichnomu» rossiyskomu obshchestvu [Modern challenges to the «archaic» Russian society]. Vestnik Permskogo universiteta, 2011, Iss. 2 (6), pp. 122-130. 
12. Malyutina N.N., Eremeev R.B., Taranenko L.A., Tolkach A.S., Kostarev V.G. Nekotorye pokazateli zdorovya rabotayushchego naseleniya Permskogo kraya i zadachi po ego ukrepleniyu na blizhayshie gody [Some indicators of the health of the working population of the Perm Territory and the tasks of strengthening it for the coming years]. Meditsina truda i promyshlennaya ekologiya, 2012, no. 12, pp. 4-8.

13. Leskina L.M., Golovkova N.P. Otsenka riska narusheniya trudovykh kollektivov [Assessment of the risk of health disorders in labor collectives]. Zdorovye i bezopasnost na rabochem meste [Health and safety at the work place]. Eds. I.V. Bukhtiyarov, T.M. Rybina. Minsk, Polycraft LLC, 2019, Vol. 1, Iss. 3. pp. 189-193.

14. Kislyakov P.A. Sistemno-lichnostnaya model zdoroveorientirovannogo obrazovaniya v vuze [Systemicpersonal model of health-oriented education at the university]. Scientific result. Seriya «Pedagogika $i$ psikhologiya obrazovaniya», 2015, no. 2, pp. 49-54.

15. Savochkin D.V., Trufanov D.O. Opyt issledovaniya sotsialnoy bezopasnosti obrazovatelnogo protsessa $\mathrm{v}$ sibirskom vuze [Experience in researching the social security of the educational process in a Siberian university]. SIBIRSKIY SOTSIUM, 2019, vol. 3, no. 1, pp. 61-72.

16. Liga M.B. Sotsialnaya bezopasnost i kachestvo zhizni: kontseptualny analiz [Social security and quality of life: conceptual analysis]. Uchenye zapiski Zabaykalskogo gosudarstvennogo universiteta. Seriya «Filosofiya, sotsiologiya, kulturologiya, sotsialnaya rabota», 2013, no. 4 (51), pp. 170-177.

17. Litvin R.I. Planirovanie sotsialnoy bezopasnosti predpriyatiya [Enterprise social security planning]. Vestnik Luganskogo natsionalnogo universiteta imeni Vladimira Dalya, 2019, no. 9 (27), pp. 157-160.

18. Ivanov S.Yu. Resurs vliyaniya profsoyuznoy kak faktor udovletvoreniya trudom [Resource of influence of the trade union organization as a factor of job satisfaction]. Materialy XVI mezhdunarodnoy nauchnoprakticheskoy konferentsii. Sotsialnoe partnerstvo: opyt, problemy i perspektivy razvitiya [Proc. XVI International comference. Social space: experience, problems and prospects of development]. Yaroslavl, ATiSO Publ., 2019. pp. 176-180.

19. Lazeva E.V. Sotsialnaya rabota na predpriyatii [Social work at the enterprise]. Nauchnoe soobshchestvo studentov XXI stoletiya. OBSHCHESTVENNYE NAUKI: sbornik statei po materialam XVII mezhdunarodnoy studencheskoy nauchno-prakticheskoy konferentsii [Research community of students of the XXI century. Social sciences. Articles on the materials pf the XVII International student scientific and practical conference]. Novosibirsk, 2014. No. 2 (17), pp. 43-48.

20. Shchelokov V.F. Kontseptualnye osnovy sotsiologicheskogo analiza kadrovoy bezopasnosti promyshlennogo predpriyatiya i ponyatie «kadrovaya sila predpriyatiya» [Conceptual foundations of sociological analysis of personnel security of an industrial enterprise and the concept of «personnel strength of an enterprise»]. Vestnik Povolzhskoy akademii gosudarstvennoy sluzhby imeni P.A. Stolypina, 2008, no. 2 (15), pp. 78-83.

21. Kirdina S.G. Institutsionalnye matritsy $i$ razvitie Rossii: vvedenie $v X-Y$ teoriyu [Institutional matrices and the development of Russia: an introduction to the X-Y theory]. St. Petersburg, Nestor-Istoriya Publ., 2014. 468 p.

22. Kareeva A.P. Sotsialnye riski sovremennogo promyshlennogo predpriyatiya [Social risks of a modern industrial enterprise]. Problemy analiza riska, 2015, no. 6 (6-15), pp. 22-30.

23. Nemirovskiy V.G. Predstavleniya naseleniya Krasnoyarskogo kraya o smysle zhizni: struktura i dinamika (1991-2016 gg.) [Perceptions of the population of the Krasnoyarsk Territory about the meaning of life: structure and dynamics (1991-2016)]. SIBIRSKIY SOTSIUM, 2018, vol. 2, no. 1, pp. 20-40.

24. Deputatova L.N., Shishkina K.A. Motivatsiya personala v predstavlenii pokoleniy [Personnel motivation in the context of the theory of generations]. Vestnik Permskogo natsionalnogo issledovatelskogo politekhnicheskogo universiteta. Sotsialno-ekonomicheskie nauki, 2019, no. 2, pp. 178-191.

25. Meyerovich M.G. Zhilishchnaya politika v SSSR kak sredstvo sotsialnogo upravleniya (1917-1941 gg.) [Housing policy in the USSR as a means of social management (1917-1941)]. SOTSIS, 2014, no. 1, pp. 95-101.

26. Grigoreva I.A. Sto let transformatsiy sotsialnoy politiki v Rossii [One hundred years of social policy transformations in Russia]. Zhurnal issledovaniy sotsialnoy politiki, 2017, no. 4, vol. 15, pp. 497-514.

27. Popova I.P., Temnitskiy A.L. Intellektualno-professionalny potentsial: k probleme strukturnykh izmeneniy [Intellectual and professional potential: to the problem of structural changes]. SOTSIS, 2011, no. 1, pp. 56-67.

28. Dmitriev A.V., Pyadukhov G.A. Integratsiya trudovykh migrantov v megapolise: lokalnye modeli, neposredstvenno kontekstnosti (metodologiya i metody issledovaniya) [Integration of labor migrants in the megalopolis: local models, context of identity (methodology and research methods)]. SOTSIS, 2013, no. 5, pp. 48-55.

29. Kozyreva P.M. Finansovoe povedenie v kontekste sotsialno-ekonomicheskoy adaptatsii naseleniya (sotsiologicheskiy analiz) [Financial behavior in the context of socio-economic adaptation of the population (sociological analysis)]. SOTSIS, 2012, no. 7, pp. 54-66.

Received: 23 December 2020. 